\title{
PENGARUH PENERAPAN GOOD GOVERNMENT GOVERNANCE DAN KOMPETENSI SUMBER DAYA MANUSIA TERHADAP KUALITAS LAPORAN KEUANGAN DAERAH (Studi Kasus pada Pemerintah Daerah di Provinsi Jawa Barat dan Banten)
}

\author{
Septi Masitoh, Dewi Sarifah Tullah, Erma Apriyanti \\ STIE PANDU MADANIA BOGOR
}

\begin{abstract}
This study aims to determine the effect of Good Government Governance and human resource competencies, on the quality of regional financial reports. The population in this study were all district / city governments in the provinces of Java and Banten. The sampling technique used is the census method. The data used are primary data, namely giving questionnaires totaling 3 sets aimed at the Head of Office and the Head of Accounting in the local governments of Java and Banten Provinces. The Head of Service fills in the questionnaire about Good Government Governance and the quality of the report, while the Head of Accounting fills in about human resource competencies. The data analysis method used is multiple linear regression analysis. The results of this study prove that Good Government Governance has a positive effect on the quality of regional financial reports in the Provinces of West Java and Banten, while human resource competence does not affect the quality of regional financial reports in the Provinces of West Java and Banten.
\end{abstract}

Key word: Good Government Governance Human Resource Competencies, and Quality of Regional Financial Statements

\section{PENDAHULUAN}

Laporan keuangan daerah merupakan sebuah informasi yang memuat data berbagai elemen struktur kekayaan dan struktur finansial yang merupakan pencerminan hasil dari aktivitas tertentu yang bisa digunakan oleh beberapa pihak yang berkepentingan sebagai dasar untuk keperluan perencanaan, pengendalian, dan pengambilan keputusan. Oleh karena itu, informasi yang terdapat di dalam Laporan Keuangan Pemerintah Daerah (LKPD) harus berkualitas dan memenuhi karakteristik kualitatif: relevan (relevance), andal (reliability), dapat dibandingkan (comparability), dan dapat dipahami (understandability) (Roviyantie, 2011).

Menurut Azis (2014), selaku ketua Badan Pemeriksa Keuangan (BPK) pada acara sosialisasi bahwa kualitas laporan keuangan pemerintah daerah rata-rata masih rendah terlihat dari daerah yang mendapat opini WTP sedikit yaitu 34\%. Opini WTP tersebut membuktikan bahwa kualitas laporan keuangan pemerintah daerah masih buruk, jika dibandingkan dengan laporan keuangan pemerintah pusat yang telah mencapai kisaran 74\%. Pada tahun 2015 beliau juga mengungkapkan bahwa kualitas laporan keuangan pemerintah daerah masih rendah, sehingga perlu perbaikan untuk mendapat opini Wajar Tanpa Pengecualian (WTP). Penurunan kualitas laporan keuangan tersebut dapat juga dilihat dalam Ikhtisar Hasil Pemeriksaan Semester 1 (IHPS) tahun 2015 bahwa selama kurun waktu lima tahun pemerintah daerah yang masih masih mendapat opini WDP $21 \%$ dan TMP 3\%, opini tersebut memperlihatkan kualitas laporan keuangan pemerintah daerah baik provinsi, kabupaten dan kota masih kurang baik.

Hasil pemeriksaan LKPD dari Tahun 2010 sampai dengan Tahun 2014 di Jawa Barat dan Banten masih ditemukannya penurunan opini dari WDP ke TMP, yaitu Kabupaten Subang (Jawa Barat), Kabupaten Pandeglang (Banten), sehingga perlu adanya perbaikan terhadap kualitas laporan keuangan pemerintah daerah Jawa Barat dan Banten agar lebih baik lagi di masa mendatang. Kualitas laporan keuangan pemerintah daerah yang buruk disebabkan beberapa faktor yang mempengaruhinya, seperti penerapan Good Government Governance (tata kelola pemerintahan yang baik). Menurut Sarosa, direktur Eksekutif Kemitraan menyatakan bahwa Good Government Governance (GGG) di Indonesia nilai paling tinggi hanya di angka 6,8 yang 
artinya cenderung baik yakni Daerah Istimewa Yogyakarta. Sehingga, penerapan Good Government Governance di Indonesia masih tergolong buruk dibandingkan nilai standar bagus Good Government Governance menurut kemitraan (2012) yakni 7,43 ke atas yang artinya sudah baik. (www.kompas.com)

Penerapan Good Government Governance sangat berpengaruh terhadap kualitas laporan keuangan daerah di mana hal ini sejalan dengan penelitian Azlim, dkk (2012) dengan judul penelitian Good Governance terhadap kualitas informasi keuangan SKPD (Satuan Kerja Perangkat Daerah) di kota Banda Aceh. Pada penelitian tersebut dinyatakan bahwa penerapan Good Governance berpengaruh terhadap kualitas informasi keuangan SKPD di Kota Banda Aceh. Penelitian Handayani (2012) dengan judul Good Governance dan Kualitas Laporan Keuangan Pemerintah tersebut menyatakan bahwa Good Governance bisa dinilai dengan melihat pada kualitas laporan keuangan pemerintah, di mana masih jeleknya tata kelola keuangan pemerintah karena masih rendahnya kualitas sumber daya manusia di pemerintahan yang belum maksimal.

Selain penerapan Good Government Governance berpengaruh terhadap kualitas laporan keuangan pemerintah daerah ada faktor lain yang berpengaruh, yaitu kompetensi Sumber Daya Manusia (SDM) mencakup kapasitasnya, yaitu kemampuan seseorang atau individu, suatu organisasi (kelembagaan), atau suatu sistem untuk melaksanakan fungsi-fungsi atau kewenangannya untuk mencapai tujuannya secara efektif dan efisien (Ihsanti, 2014). Kapasitas harus dilihat sebagai kemampuan untuk mencapai kinerja, untuk menghasilkan keluaran-keluaran (outputs) dan hasilhasil (outcomes). Oleh karena itu, jika kompetensi SDM tidak sesuai dengan pendidikannya di luar akuntansi, maka akan berdampak terhadap Kualitas laporan keuangan daerah. Sehingga, kualitas laporan keuangan tersebut menjadi tidak akurat karena tidak dikelola oleh SDM yang berlatar belakang pendidikan akuntansi.

Sebaik apapun suatu sistem akan sia-sia begitu saja, apabila tidak didukung kualitas SDM yang memadai, khususnya kualitas pribadi SDM yang terdiri dari potensi pendidikan, pengalaman, dan pelatihan (Indriasih, 2014). SDM yang berkualitas dapat menghemat waktu pembuatan laporan keuangan, karena SDM tersebut telah mengetahui dan memahami apa yang akan dikerjakan dengan baik, sehingga penyajian laporan keuangan bisa terselesaikan tepat waktu. Semakin cepat waktu penyajian laporan keuangan maka semakin baik untuk pengambilan keputusan (Mardiasmo, 2002).

Asisten VI Bidang Administrasi Pemerintah Provinsi Jawa Barat, Karniwa (2011) juga menyatakan bahwa minimnya tenaga SDM yang memiliki latar belakang akuntansi dan auditor masih menjadi kendala dalam penyusunan laporan keuangan pemerintah daerah yang menyebabkan kualitas Laporan Keuangan Pemerintah Daerah (LKPD) buruk. Roviyantie (2014) dalam penelitiannya menyatakan bahwa secara garis besar kompetensi sumber daya manusia yang ada di pemerintah daerah Kabupaten Tasikmalaya berpengaruh terhadap kualitas LKPD. Artinya bahwa semakin kompeten SDM pembuat laporan keuangan, maka semakin baik pula kualitas LKPD yang dihasilkan. Berdasarkan hasil penelitian tersebut menunjukan bahwa kompetensi sumber daya manusia memiliki andil yang sangat penting dalam proses penyusunan laporan keuangan pemerintah daerah.

Berdasarkan fenomena rendahnya kualitas laporan keuangan pemerintah daerah, sehingga diperlukan pembenahan terhadap penerapan Good Government Governance dan kompetensi sumber daya manusia. Di mana jika Good Government Governance dan kompetensi sumber daya manusia telah terpenuhi, maka kualitas laporan keuangan pemerintah daerah yang baik akan dapat tercapai. Oleh karenanya pada kesempatan kali ini, penulis ingin mengambil penelitian dengan judul "Pengaruh Penerapan Good Government Governance dan Kompetensi Sumber Daya Manusia Terhadap Kualitas Laporan Keuangan Daerah (Studi Kasus pada Pemerintah Daerah di Provinsi Jawa Barat dan Banten)",

\section{TINJAUAN TEORETIS \\ Good Government Governance}

Pengertian Good Governance sering diartikan sebagai kepemerintahan yang baik. Dalam rapat kerja nasional Akuntansi 2011, dijelaskan bahwa istilah good governance sendiri pertama kali digunakan pada World Development Report tahun 1989 yang mengacu pada penyelenggaraan pemerintahan yang amanah dan bertanggung jawab, tata kelola pemerintahan yang baik serta pemerintahan yang bersih.

Pemerintah dapat dikatakan baik, jika produktif dan memperlihatkan hasil dengan indikator kemampuan ekonomi rakyat meningkat baik dalam aspek produktivitas maupun dalam daya belinya, kesejahteraan spiritualitasnya terus 
meningkat dengan indikator rasa aman, tenang, dan bahagia serta sense of nationality yang baik Penerapan prinsip-prinsip GGG pada dasarnya merupakan perwujudan keamanahan pengelola dalam menjalankan tugas yang diamanatkan kepadanya dan kejujuran dalam laporan keuangan. Keamanahan dan kejujuran tersebut membentuk integritas para pemimpin bangsa ini.

Menurut Undang-undang Nomor 13 Tahun

2003 tentang keuangan negara menjelaskan ada 5 (lima) prinsip Good Governance yang digunakan dalam instansi pemerintahan, yaitu:

1. Asas akuntabilitas berorientasi pada hasil

2. Asas proporsionalitas adalah asas yang mengutamakan keseimbangan

3. Asas profesionalitas adalah asas yang mengutamakan keahlian

4. Asas keterbukaan dan pengelolaan keuangan negara adalah asas yang membuka diri

5. Asas pemeriksaan keuangan oleh badan pemeriksaaan yang bebas dan mandiri

Good Governance memiliki beberapa prinsip yang dikaitkan dengan laporan keuangan. Dalam (Kuntadi. 2011), prinsip-prinsip good governance tersebut diuraikan sebagai berikut :

1. Prinsip Kewajaran (Fairness

2. Prinsip akuntabilitas

3. Prinsip transparansi

4. Prinsip responsibilitas,

Karakteristik pelaksanaan good governance menurut

UNDP (Mardiasmo, 2002), yaitu :

1. Partisipasi, yaitu keterlibatan masyarakat

2. Rule of law, kerangka hukum yang adil

3. Transparansi, dibangun atas dasar kebebasan memperoleh informasi.

4. Responsiveness, lembaga-lembaga publik harus cepat dan tanggap dalam melayani stakeholder.

5. Consensus orientation, berorientasi pada kepentingan masyarakat yang lebih luas.

6. Equity, setiap masyarakat memiliki kesempatan yang sama

7. Efficiency and effectiveness, pengelolaan sumber daya publik dilakukan secara efisien dan efektif.

8. Accountability, pertanggungjawaban kepada publik

9. Strategic vision, penyelenggara pemerintahan dan masyarakat harus memiliki visi jauh kedepan.

\section{Kompetensi Sumber Daya Manusia}

Kompetensi sumber daya manusia mencakup kapasitasnya, yaitu kemampuan seseorang atau individu, suatu organisasi (kelembagaan), atau suatu sistem untuk melaksanakan fungsi-fungsi atau kewenangannya untuk mencapai tujuannya secara efektif dan efisien. apasitas harus dilihat sebagai kemampuan untuk mencapai kinerja, untuk menghasilkan keluarankeluaran (outputs) dan hasil-hasil (outcomes).

Hutapea dan Thoha (2008), mengungkapkan bahwa ada tiga komponen utama pembentukan kompetensi yaitu pengetahuan yang dimiliki seseorang, kemampuan, dan prilaku individu.

Sonny Sumarsono (2003), sumber daya manusia atau human recources mengandung dua arti. Pertama adalah usaha kerja atau jasa yang dapat diberikan dalam proses produksi. Dalam hal lain sumber daya manusia mencerminkan kualitas usaha yang diberikan oleh seseorang dalam waktu tertentu untuk menghasilkan barang dan jasa. Pengertian kedua sumber daya manusia menyangkut manusia yang mampu bekerja untuk memberikan jasa atau usaha kerjan tersebut. Mampu bekerja berarti mampu melakukan kegiatan yang mempunyai kegiatan ekonomis yaitu bahwa kegiatan tersebut menghasilkan barang atau jasa untuk memenuhi kebutuhan atau masyarakat.

\section{Komponen sumber Daya Manusia}

Menurut Hasibuan (2002) membagi komponen SDM sebagai berikut:

1. Pengusaha

2. Karyawan posisi karyawan dalam suatu perusahaan dibedakan menjadi:

a. Karyawan operasional

b. Karyawan Manajeril

3. Pemimpin

\section{Kualitas Laporan Keuangan Daerah}

Menurut Peraturan Pemerintah Nomor 71 Tahun 2010 laporan keuangan merupakan laporan yang terstruktur mengenai posisi keuangan dan transaksi-transaksi yang dilakukan oleh suatu entitas pelaporan.

Laporan keuangan (financial statements) terdiri dari :

a. Neraca (balance sheet)

b. Laporan laba rugi (income statement)

c. Laporan perubahan ekuitas (statement of changes of equity)

d. Laporan arus kas (cash flow statement)

e. Catatan atas laporan keuangan (notes to financial statemen)

Laporan keuangan haruslah memenuhi karakteristik kualitatif (qualitative characteristics) tertentu agar dapat memberikan informasi yang berguna bagi para pemakai, karakteristik kualitatif (qualitative characteristics). 


\section{Pelaporan Keuangan (Financial Reporting)}

Menurut SFAC (Statement of Financial Accounting Concepts) Nomor 1 tentang Objectives of Financial Reporting by Business Enterprises, tujuan pelaporan keuangan adalah:

a. Menyediakan informasi yang berguna bagi investor, kreditor, dan pengguna potensial lainnya dalam membantu proses pengambilan keputusan yang rasional atas investasi, kredit dan keputusan lain yang sejenis.

b. Menyediakan informasi yang berguna bagi investor, kreditor, dan pengguna potensial lainnya yang membantu dalam menilai jumlah, waktu dan ketidak pastian prospek penerimaan kas dari deviden atau bunga dan pendapatan dari penjualan, penebusan atau jatuh tempo sekuritas atau pinjaman. Menaksir aliran kas masuk (future cash flow) pada perusahaan.

c. Memberikan informasi tentang sumber daya ekonomi, dan klaim atas sumber daya tersebut serta perubahannya.

\section{METODE PENELITIAN}

Penelitian ini dilakukan pada dinas pengelolaan keuangan daerah di Provinsi Jawa Barat dan Banten Waktu pelaksanaan penelitian dilakukan selama 3 (tiga) bulan yang dimulai pada bulan Januari sampai Maret 2017. populasi sasaran adalah dinas pengelolaan keuangan daerah di wilayah Provinsi Jawa Barat dan Banten sejumlah 37 pemda. Sampel dari penelitian ini adalah menggunakan metode sensus, dikarenakan ada 4 pemda yang tidak mengembalikan kuesioner maka yang di jadikan sampel sejumlah 33 pemda.

Metode penelitian yang digunakan dalam penelitian ini adalah metode pengujian hipotesis dan analisis studi kasus pada pemerintah daerah di Provinsi Jawa Barat dan Banten.

\section{HASIL PENELITIAN DAN PEMBAHASAN}

Deskripsi Kuesioner tentang Penerapan Good Government Governance

Tabel 1

Tanggapan Responden Terhadap Integritas

\begin{tabular}{|c|c|c|c|c|c|c|c|c|c|c|c|c|}
\hline \multirow{2}{*}{$\begin{array}{l}\text { No } \\
\text { Item }\end{array}$} & \multicolumn{8}{|c|}{ Frekuensi Jawaban } & \multirow{2}{*}{\multicolumn{4}{|c|}{ 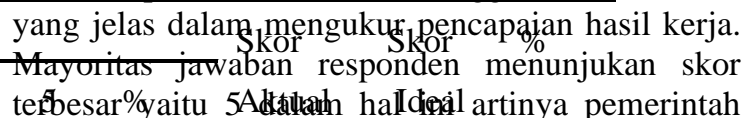 }} \\
\hline & 1 & $\%$ & 2 & $\%$ & 3 & $\%$ & 4 & $\%$ & & & & \\
\hline 1 & 0 & $0 \%$ & 0 & $0 \%$ & 5 & $15 \%$ & 1 & $3 \%$ & \multirow{2}{*}{\multicolumn{4}{|c|}{ 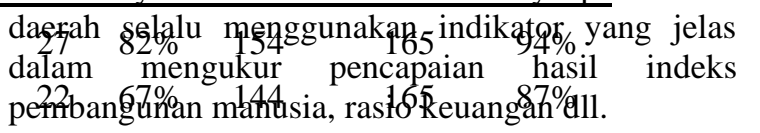 }} \\
\hline 2 & 1 & $3 \%$ & 2 & $6 \%$ & 3 & $9 \%$ & 5 & $15 \%$ & & & & \\
\hline 3 & 0 & $0 \%$ & 0 & $0 \%$ & 3 & $9 \%$ & 4 & $12 \%$ & $79 \%$ & 155 & 165 & $94 \%$ \\
\hline Sko & & & & & & & & & & 453 & 495 & $92 \%$ \\
\hline
\end{tabular}

Sumber: Kuesioner ( Data Diolah 2017)
Data di atas diketahui bahwa mayoritas responden memilih jawaban nomor 5 yaitu pimpinan pemerintah daerah Provinsi Jawa Barat dan Banten selalu menerapkan budaya kerja dengan berlaku jujur dan berdiri sebagai panutan bagi anak buah dan masyarakat.

Tabel 2

Tanggapan responden terhadap Keterbukaan

\begin{tabular}{|c|c|c|c|c|c|c|c|c|c|}
\hline \multirow{2}{*}{$\begin{array}{l}\text { No } \\
\text { Item }\end{array}$} & \multicolumn{9}{|c|}{ Frekuensi jawaban } \\
\hline & 1 & $\%$ & 2 & $\%$ & 3 & $\%$ & 4 & $\%$ & 5 \\
\hline 1 & 1 & $3 \%$ & 2 & $6 \%$ & 10 & $30 \%$ & 5 & $15 \%$ & 15 \\
\hline 2 & 0 & $0 \%$ & 2 & $6 \%$ & 6 & $18 \%$ & 6 & $18 \%$ & 19 \\
\hline 3 & 0 & $0 \%$ & 1 & $3 \%$ & 10 & $30 \%$ & 8 & $24 \%$ & 14 \\
\hline
\end{tabular}

Skor Total

Sumber: Kuesioner ( Data Diolah 2017)

Data di atas diketahui bahwa mayoritas responden menjawab dengan skor 5 yaitu menyatakan $100 \%$ informasi diungkapkan dalam pengelolaan keuangan pemerintah daerah, kebijakan di pemerintah daerah Provinsi Jawa Barat dan Banten memberikan informasi keuangan secara terbuka kepada masyarakat dalam publikasi resmi, yang berarti bahwa pemerintah daerah Provinsi Jawa Barat dan Banten sudah sangat terbuka atas informasi pengelolaan keuangannya.

Tabel 3

Tanggapan Responden Terhadap Hasil

\begin{tabular}{llllllllll} 
No & \multicolumn{1}{l}{ Frekuensi jawaban } \\
\cline { 2 - 9 } Item & 1 & $\%$ & 2 & $\%$ & 3 & $\%$ & 4 & $\%$ & 5 \\
\hline 1 & 0 & $0 \%$ & 0 & $0 \%$ & 5 & $15 \%$ & 8 & $26 \%$ & 20 \\
2 & 0 & $0 \%$ & 1 & $3 \%$ & 4 & $12 \%$ & 4 & $15 \%$ & 24 \\
\hline
\end{tabular}

Skor Total

Sumber: Kuesioner ( Data Diolah 2017)

Data di atas diketahui bahwa indikator bahan evaluasi, pemerintah daerah menggunakan indikator

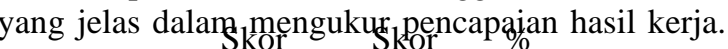
Mayoritas jawaban responden menunjukan skor dazłah selalu męnggunakap 5 indikat $46 \%$ yang jelas dalam mengukur pencapaian hasil indeks 
Tabel 4

Tanggapan Responden Terhadap Intervensi

\begin{tabular}{lllllllll}
\multirow{2}{*}{$\begin{array}{l}\text { No } \\
\text { Item }\end{array}$} & 1 & $\%$ & 2 & $\%$ & 3 & $\%$ & 4 & $\%$ \\
\cline { 2 - 9 } 1 & 0 & $0 \%$ & 0 & $0 \%$ & 5 & $15 \%$ & 10 & $30 \%$ \\
2 & 0 & $0 \%$ & 1 & $3 \%$ & 8 & $24 \%$ & 15 & $46 \%$ \\
\hline Skor Total & \\
Sumber : Kuesioner ( Data Diolah 2017) \\
Data di atas diketahui bahwa indikator pada \\
kebijakan yang diambil pemerintah daerah Provinsi \\
Jawa Barat dan Banten dilakukan secara terperinci \\
sudah baik kegiatannya, dapat dilihat dari jawaban \\
responden dengan skor tertinggi yaitu 5 dengan \\
persentase 55\%.
\end{tabular}

Tabel 5

Tanggapan Responden Terhadap Kapasitas

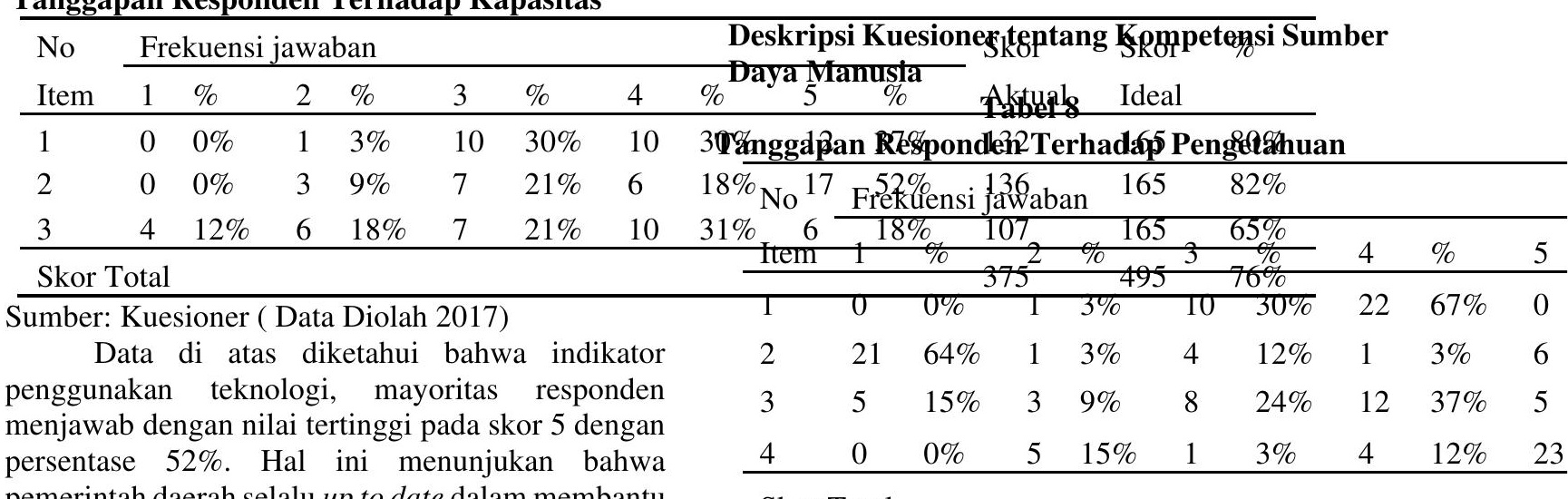
pemerintah daerah selalu up to date dalam membantu pelaksanaan kebijakan lembaga.

$$
\text { Tabel } 6
$$

Tanggapan Responden Terhadap Manajemen Resiko dan Kinerja

\begin{tabular}{lllllllll} 
No & \multicolumn{1}{c}{ Frekuensi jawaban } \\
\cline { 2 - 9 } Item & 1 & $\%$ & 2 & $\%$ & 3 & $\%$ & 4 & $\%$ \\
\hline 1 & 0 & $0 \%$ & 1 & $3 \%$ & 6 & $18 \%$ & 10 & $29 \%$ \\
2 & 0 & $0 \%$ & 1 & $3 \%$ & 5 & $15 \%$ & 10 & $29 \%$ \\
3 & 0 & $0 \%$ & 0 & $0 \%$ & 5 & $15 \%$ & 7 & $24 \%$ \\
\hline Skor Total & \\
Sumber: data diolah ( Data Diolah 2017) \\
Data di atas diketahui bahwa indikator \\
pengendalian atas fisik asset. Responden terbanyak \\
menjawab dengan skor 5, hal ini menunjukan bahwa \\
pemerintah daerah dengan cara melakukan \\
identifikasi, kebijakan dan prosedur pengamanan \\
fisik yang dilakukan secara teratur dan setiap saat \\
dilakukan.
\end{tabular}

Tabel 7

Tanggapan Responden Terhadap Akuntabilitas No Freku\&ksirjawabskor \%

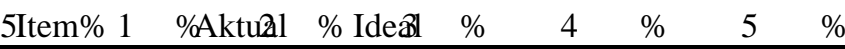

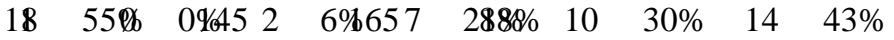

$\begin{array}{llllllllll}92 & 2706 & 0 \% 31 & 0 & 0 \% 653 & 97 \% \% & 12 & 36 \% & 18 & 55 \%\end{array}$

$\begin{array}{llll}\text { Skor Total } 276 \quad 330 & 84 \%\end{array}$

Sumber: data diolah ( Data Diolah 2017)

Data di atas diketahui bahwa indikator laporan keuangan yang sudah diaudit. Mayoritas responden memberikan tanggapan terbesar yaitu skor 5 dengan persentase $43 \%$. Hal ini menunjukan bahwa pemerintah daerah Provinsi Jawa Barat dan Banten mengumumkan laporan keuangan yang sudah diaudit setiap tahun dan memberi informasi secara terbuka kepada masyarakat lewat media selalu dilakukan dengan baik.

Skor Total

Sumber: data diolah ( Data Diolah 2017)

Data di atas diketahui bahwa mayoritas responden memilih jawaban nomor 4 yaitu komepensi aparah Provinsi Jawa Baratskan Bansopseriqg melakukan pelatihan dan keahlian khusus di bidang akuntansi sehingga 5 kompetens Aktual wrideal erintah selalu meningkat.

$16 \quad 47 \% \quad 140 \quad$ Tabel $985 \%$

17 T3anggapan responden terhadap Skill

$21 \quad \mathrm{~N} \% \%$ Frekuensijawaban

Skor Total

Sumber: data diolah ( Data Diolah 2017)

Data di atas diketahui bahwa mayoritas

\begin{tabular}{|c|c|c|c|c|c|c|c|c|}
\hline Item & $13 \% \%$ & 25 & $\%$ & 3 & $\%$ & 4 & $\%$ & 5 \\
\hline 1 & $6 \%$ & 4 & $12 \%$ & -12 & $36 \%$ & 1 & $3 \%$ & 14 \\
\hline 2 & $0 \%$ & 1 & $3 \%$ & 7 & $21 \%$ & 21 & $64 \%$ & 4 \\
\hline 3 & $0 \%$ & 2 & $6 \%$ & 14 & $43 \%$ & 14 & $42 \%$ & 3 \\
\hline
\end{tabular}
responden menjawab dengan skor 4 yaitu 
menyatakan bahwa aparatur pemerintah daerah Provinsi Jawa Barat dan Banten terampil dalam menyusun, meriview dan menganalisa laporan keuangan secara lengkap.

Tabel 10

\section{Tanggapan Responden Terhadap Sikap}

No Frekuensi jawaban
Tabel 12

Tanggapan Responden Terhadap Relevan

No Frekuensi Jawaban

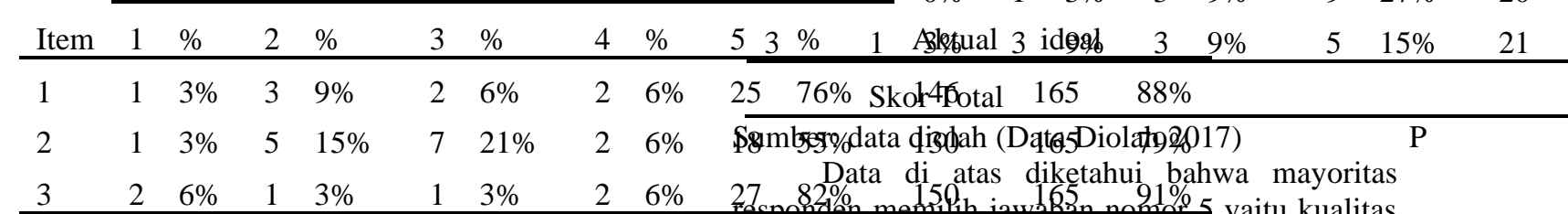

Skor Total

Sumber: data diolah ( Data Diolah 2017)

Data di atas diketahui bahwa mayoritas jawaban responden menunjukan skor terbesar yaitu 5 , dalam hal ini artinya responden memiliki sikap rasional dalam setiap melakukan pekerjaan dan mengambil keputusan, serta mampu mengatasi masalah dan mengambil keputusan yang tepat.

Tabel 11

Tanggapan Responden Terhadap Pengalaman lelaporan keupargan p\$9merint $\$ 6 \%$ daerah Provinsi

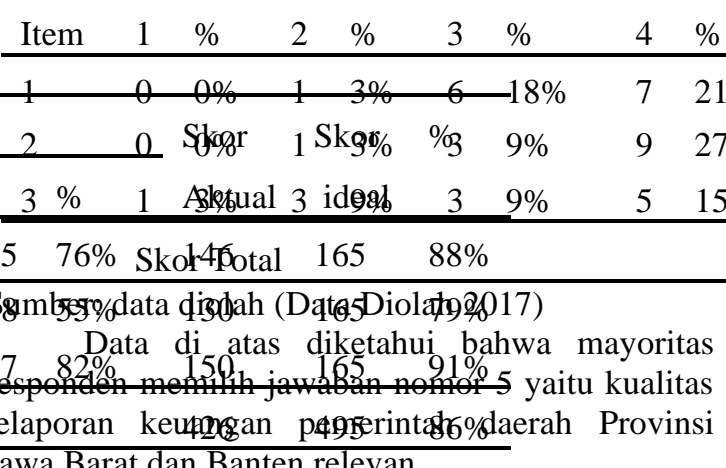
Jawa Barat dan Banten relevan.

\section{Tabel 13}

Tanggapan Responden Terhadap Andal

\begin{tabular}{|c|c|c|c|c|c|c|c|c|c|}
\hline \multirow{2}{*}{$\begin{array}{l}\text { No } \\
\text { Item }\end{array}$} & \multicolumn{9}{|c|}{ Frekuensi Jawaban } \\
\hline & 1 & $\%$ & 2 & $\%$ & 3 & $\%$ & 4 & $\%$ & 5 \\
\hline 1 & 1 & $3 \%$ & 0 & $0 \%$ & 2 & $6 \%$ & 3 & $9 \%$ & 27 \\
\hline 2 & 0 & $0 \%$ & 1 & $3 \%$ & 8 & $24 \%$ & 2 & $6 \%$ & 22 \\
\hline 3 & 0 & $0 \%$ & 0 & $0 \%$ & 5 & $15 \%$ & 1 & $3 \%$ & 27 \\
\hline
\end{tabular}

\begin{tabular}{lllllllll} 
No & \multicolumn{7}{l}{ Frekuensi jawaban } \\
\cline { 2 - 8 } Item & 1 & $\%$ & 2 & $\%$ & 3 & $\%$ & 4 & $\%$ \\
\hline 1 & 6 & $18 \%$ & 5 & $15 \%$ & 5 & $15 \%$ & 2 & $6 \%$ \\
2 & 15 & $46 \%$ & 3 & $9 \%$ & 3 & $9 \%$ & 3 & $9 \%$ \\
3 & 6 & $18 \%$ & 5 & $15 \%$ & 3 & $9 \%$ & 4 & $12 \%$ \\
4 & 12 & $37 \%$ & 5 & $15 \%$ & 5 & $15 \%$ & 1 & $3 \%$ \\
\hline
\end{tabular}

Skor Total

Sumber : data diolah ( Data Diolah 2017)

Data di atas diketahui bahwa mayoritas jawaban responden menunjukan skor terbesar yaitu 5 dalam hal ini artinya mayoritas responden sudah berpengalaman bekerja di bidang akuntansi.

\section{Deskripsi Kuesioner tentang Kualitas Laporan Keuangan}

Di bawah ini disajikan data hasil kuesioner Kualitas Laporan Keuangan. Jawaban hasil kuesioner diberikan skor pada tiap item dari 1-5. Selain itu, pada Tabel 4.17 dapat dilihat hasil dari tanggapan responden terhadap indikator relevan berikut ini.

Skskorotal Skor \%

$5^{\text {Sumber :data displah (Datapiolah 2017) }}$

5 Data di atas diketahui bahwa mayoritas 1 respofferen hlthjawab 165 denga $69 \%$ skor 5 yaitu

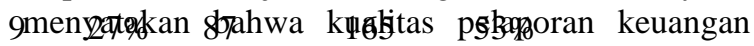
15 emerintah daerah Proyinsi Jawa Barat dan Banten sesuai dengan anggaran pendapatan dan belanja. $\begin{array}{lllll}10 & 30 \% & 91 & \text { Table } \mathbf{5 1 4} \quad 55 \%\end{array}$

\section{Tanggapap Responden Terhadap Dapat}

\begin{tabular}{|c|c|c|c|c|c|c|c|c|c|}
\hline \multirow{2}{*}{$\begin{array}{l}\text { No } \\
\text { Item }\end{array}$} & \multicolumn{9}{|c|}{ Frekuensi Jawaban } \\
\hline & 1 & $\%$ & 2 & $\%$ & 3 & $\%$ & 4 & $\%$ & 5 \\
\hline 1 & 0 & $0 \%$ & 0 & $0 \%$ & 5 & $15 \%$ & 20 & $61 \%$ & 8 \\
\hline 2 & 2 & $6 \%$ & 20 & $61 \%$ & 4 & $12 \%$ & 1 & $3 \%$ & 6 \\
\hline 3 & 12 & 37 & 4 & $12 \%$ & 5 & $15 \%$ & 1 & $3 \%$ & 11 \\
\hline \multicolumn{10}{|c|}{ Skor Total } \\
\hline \multicolumn{10}{|c|}{$\begin{array}{l}\text { Sumber: data diolah (Data Diolah } 2 \\
\text { Data di atas diketahui bahwa may } \\
\text { jawaban responden menunjukkan skor terbesar } \\
4 \text { dengan persentase } 61 \% \text {. } \\
\text { Tabel } 15 \\
\text { Tanggapan Responden Terhadap Dipahami }\end{array}$} \\
\hline No & \multicolumn{9}{|c|}{ Frekuensi Jawaban } \\
\hline Item & 1 & $\%$ & $\%$ & 3 & $\%$ & 4 & $\%$ & & 5 \\
\hline 1 & 0 & $0 \%$ & $0 \%$ & 4 & $12 \%$ & 17 & & $2 \%$ & 12 \\
\hline 2 & 1 & $3 \%$ & $3 \%$ & 9 & $27 \%$ & 2 & & & 20 \\
\hline \multicolumn{10}{|c|}{ Skor Total } \\
\hline
\end{tabular}


Sumber : data diolah (Data Diolah 2017)

Data di atas diketahui bahwa mayoritas jawaban responden menunjukan skor terbesar yaitu 5 dengan persentase $61 \%$.

Pembahasan

Pembahasan ini akan menguraikan tentang pengaruh Good Government Governance dan kompetensi sumber daya manusia terhadap kualitas laporan keuangan daerah berdasarkan hasil pengolahan data menggunakan SPSS versi 16.0.

\section{Pengaruh Good Government Governance terhadap Kualitas Laporan Keuangan}

Hasil pengujian hipotesis pertama, ditemukan adanya bukti yang menunjukkan bahwa terdapat pengaruh yang signifikan antara penerapan Good Government Governance terhadap kualitas informasi laporan keuangan daerah pada pemerintah daerah di Provinsi Jawa Barat dan Banten. Berdasarkan hasil tersebut maka hipotesis ketiga (H1) diterima. Hal ini berarti bahwa Good Government Governance berpengaruh positif dan signifikan terhadap kualitas laporan keuangan pemerintah daerah.

Hasil penelitian ini sejalan dengan penelitian yang dilakukan oleh Azlim, dkk (2012), bahwa variabel Good Government Governance berpengaruh terhadap kualitas laporan keuangan. Penerapan prinsip-prinsip Good Government Governance dalam penyelengaraan kepemerintahan juga tidak lepas dari masalah akuntabilitas dan transparasi dalam pengelolaan keuangan daerah sebagai acuan dalam menghasilkan laporan keuangan yang berkualitas. Sejalan dengan penelitian Batubara (2006) yang menyebutkan bahwa penerapan Good Government Governance merupakan tuntutan dari pembaharuan sistem keuangan. Selain itu, penelitian ini juga mendukung penelitian yang dilakukan oleh Efanita (2013) yang menyebutkan bahwa penerapan prinsip-prinsip Good Government Governance dalam penyelenggaraan pemerintahan sangat diperlukan, sehingga dalam pengelolaan keuangan daerah dapat menghasilkan informasi laporan keuangan yang berkualitas.

Hasil wawancara yang telah di dapatkan, dimana pada pemerintah daerah di Provinsi Jawa Barat dan Banten telah menerapkan prinsip Good Government Governance. Hal ini dapat dibuktikan dengan adanya transparansi atau keterbukaan bagi stakeholder. Selain adanya transparansi, pemerintah daerah di Provinsi Jawa Barat dan Banten juga telah menganut prinsip akuntabilitas yaitu menetapkan setiap rincian tugas dan tanggungjawab pada masing-masing bidang bahkan individu dan membuat laporan keuangan guna melaporkan segala bentuk transaksi atau kegiatan yang telah terjadi selama satu periode pelaporan akuntansi. Penerapan Good Government Governance juga didukung dengan adanya prinsip responsibilitas yakni adanya pelaksanaan kegiatan-kegiatan organisasi yang telah disusun sebelumnya berdasarkan peraturan dan kebijakan yang berlaku. Selanjutnya adanya prinsip independensi yakni dalam melaksanakan kegiatan organisasi tidak adanya intervensi atau pengaruh dari pihak lain.

\section{Pengaruh Kompetensi Sumber Daya Manusia terhadap Kualitas Laporan Keuangan \\ Berdasarkan hasil pengolahan data,} kompetensi sumber daya manusia tidak memiliki pengaruh terhadap kualitas laporan keuangan. Berdasarkan hasil tersebut maka hipotesis kedua (H2) ditolak. Hal ini menunjukkan bahwa kompetensi sumber daya manusia tidak berpengaruh terhadap kualitas laporan keuangan pemerintah daerah.

Penelitian ini sejalan dengan Ahmad Syarifudin (2014) yang menyatakan bahwa kompetensi sumber daya manusia tidak berpengaruh signifikan terhadap kualitas laporan keuangan daerah. Selain itu, penelitian ini sejalan dengan penelitian yang dilakukan Zuliarti (2012) yang menghasilkan kapasitas sumber daya manusia tidak berpengaruh terhadap kualitas pelaporan keuangan. Hal ini disebabkan karena kondisi kapasitas sumber daya manusia yang belum mendukung baik dari segi kualitas maupun kuantitas.

Dari sisi kualifikasi, sebagian besar pegawai bagian akuntansi/keuangan tidak memiliki latar belakang pendidikan akuntansi. Dari sisi kuantitas, masih sedikit jumlah akuntan atau pegawai yang berpendidikan tinggi akuntansi dan kurangnya mengikuti pelatihan-pelatihan yang berhubungan akuntansi dan pengelolaan keuangan daerah, sementara peraturan perundang-undang telah mewajibkan setiap satuan kerja untuk menyelenggarakan akuntansi dan menyusun laporan keuangan. Oleh sebab itu, kelemahan yang ada harus diimbangi dengan mengikuti seminar atau pelatihanpelatihan di bidang akuntansi bagian keuangan, penatausahaan keuangan, sistem informasi manajemen daerah dan sebagainya.

Variabel kompetensi sumber daya manusia tidak berpengaruh terhadap kualitas laporan keuangan daerah karena kondisi kapasitas sumber daya manusia dibagian akuntansi/keuangan di pemerintah daerah Provinsi Jawa Barat dan Banten memiliki latar belakang pendidikan akuntansi yang belum mendukung karena masih sedikit yaitu sebesar $38.2 \%$ pegawai sub-bagian 
akuntansi/keuangan yang memiliki latar belakang pendidikan akuntansi.

\section{SIMPULAN DAN SARAN}

Penelitian ini bertujuan untuk menguji pengaruh penerapan Good Government Governance dan kompetensi sumber daya manusia terhadap kualitas pelaporan keuangan daerah di Provinsi Jawa Barat dan Banten. Hipotesis dalam penelitian ini diuji dengan menggunakan persamaan regresi linier berganda. Berdasarkan hasil analisis dan pembahasan yang telah diuraikan pada bab sebelumnya, dapat disimpulkan bahwa :

1. Good Government Governance berpengaruh terhadap kualitas laporan keuangan pemerintah daerah di Provinsi Jawa Barat dan Banten.

2. Kompetensi sumber daya manusia tidak berpengaruh terhadap kualitas laporan keuangan pemerintah daerah di Provinsi Jawa Barat dan Banten.

\section{Saran}

Dari hasil dan pembahasan penelitian ini, berdasakan kesimpulan penelitian ini, maka saran dari penelitian ini sebagai berikut.

1. Peneliti selanjutnya diharapkan untuk bisa mendapatkan data secara keseluruhan dari semua dinas/badan/kantor yang ada, agar hasil yang didapat lebih maksimal atau menambah sampel penelitian pada SKPD lain yang belum ada di dalam penelitian.

2. Diharapkan bagi pegawai yang bertugas atau terlibat langsung dalam penyajian dan penyusunan laporan keuangan agar dapat meningkatkan pemahaman dan penguasaan tentang Good Government Governance dalam aspek integritas dengan meningkatkan budaya kerja sesuai dengan norma, komitmen terhadap nilai etis serta meningkatkan peranan hukum.

Peneliti selanjutnya supaya dapat mempertimbangkan untuk menambahkan variabelvariabel lain yang diduga berpengaruh terhadap kualiatas laporan keuangan daerah.

\section{DAFTAR PUSTAKA}

Azlim, Darwanis, dan Usman. 2012. Pengaruh Penerapan Good Governance Dan SAP terhadap Kualitas Informasi Keuangan SKPD di Kota Banda Aceh. Jurnal Akuntansi ISSN 2302-0164 Pascasarjana Universitas Syiah Kuala.

Bastian Indra, 2001, Akuntansi Sektor Publik di Indonesia, Yogyakarta, BPFE, 2001.
Desiana, Wati Kadek dkk. 2014. Pengaruh Kompetensi Sumber Daya Manusia, Penerapan Standar Akuntansi Pemerintah, dan Sistem Akuntansi Keuangan Daerah terhadap Kualitas Laporan Keuangan Daerah. e-Journal Volume 2 No:1 Jurusan Akuntansi Program S1 Universitas Pendidikan Ganesha .

Efanita, Waode Viyani. 2013. Pengaruh Penerapan Good Government Governance dan Standar Akuntansi Pemerintah terhadap Kualitas Informasi Laporan Keuangan pada Dinas Koperasi dan UMKM Kab. Buton. Skripsi. Kendari : Jurusan Akuntansi Universitas Halu Oleo

Handayani, Desi. 2012. Good Governance dan Kualitas Laporan Keuangan Pemerintah. Jurnal Akuntansi Keuangan dan Bisnis Vol.5 Politeknik Caltex Riau.

Ihsanti, Emilda. 2014. Pengaruh kompetensi Sumber Daya Manusia dan Penerapan Sistem Akutansi Keuangan Daerah terhadap Kualitas Laporan Keuangan Daerah (Studi Empiris pada SKPD Kab. Lima Puluh Kota). Jurnal Akuntansi. Fakultas Ekonomi. UNP. Padang.

Kuntadi, Cris. 2011. Peran Akuntansi dan Audit dalam Transformasi Tata Kelola (Good Governance) Instansi Pemerintah yang Akuntabel, Transparan, dan Berbasis Kinerja.

Mahmudi, 2005. Manajemen Kinerja Sektor Publik. Yogyakarta: UPP AMP YKPN.

Mardiasmo. 2002. Akuntansi sektor Publik. Yogyakarta : Penerbit Andi.

Peraturan Pemerintah Nomor 71 Tahun 2010 tentang Standar Akuntansi Pemerintah.

Rakernas Akuntansi 2011 : Langkah Menuju Perwujudan Good Governance dan Peningkatan Kualitas Laporan Keuangan Pemerintah Pusat.

Roviyantie, Devi. 2012. Pengaruh kompetensi Sumber Daya Manusia dan Penerapan Sistem Akuntansi Keuangan Daerah Terhadap Kualitas Laporan Keuangan Daerah. (Survey pada Organisasi Peranokat Drorah (OPD) Kabupaten Tasikmalaye Strid Akuntansi Fakultas E rsi Siliwangi.

Sefri, Yensi Desy. 2014. Pengaruh Kompetensi Sumber Daya Manusia, Penerapan Sistem Akuntansi Keuangan Daerah, Dan Sistem Pengendalian Intern (Internal Audit) Terhadap Kualitas Laporan Keuangan Pemerintah Daerah (Studi Empiris pada SKPD Kabupaten Kuantan Singingi). JOM FEKON Vol. 1 Fakultas Ekonomi Universitas Riau, Pekanbaru. 
Sumodiningrat, Gunawan. 1999. Pemberdayaan Masyarakat \& JPS. Jakarta: PT Gramedia Pustaka Utama.

Supriyadi, Edy.2014. SPSS+AMOS Statistical Data Analysis. Jakarta.In Media.

Syarifudin, Akhmad. 2014. Pengaruh Kompetensi SDM dan Peran Audit Intern terhadap Kualitas Laporan Keuangan Pemerintah Daerah dengan Variabel Intervening Sistem Pengendalian Internal Pemerintah (studi empiris pada Pemkab Kebumen). Jurnal Fokus Bisnis, Volume 14, No 02.

Thufail. 2002. Good Governance Мenuju Kehidupan Demokratis, Hand Out Kuliah Civic Education.

World Bank. 2004. Mainstreaming Anticorruption Activities in World Bank Assistance: A Review of Progress since 1997. Washington, DC: World Bank.

Zeyn, Elfira. 2011. Pengaruh Good Government dan standar Akuntansi Pemerintahan Terhadap Akuntabilitas Keuangan dengan Komitmen Organisasi Sebagai Pemoderisasi. Jurnal Review Akuntansi dan Keuangan. ISSN : 20880685 Vol.1 No.1 Pp. 21-37

Zuliarti. 2012. Pengaruh Kapasitas Sumber Daya Manusia, Pemanfaatan Teknologi Informasi, dan Pengendalian Intern Akuntansi terhadap Nilai Informasi Pelaporan Keuangan Pemerintah Daerah (studi pada pemerintah Kabupaten Kudus). Skripsi (dipublikasikan). Program Studi Akuntansi Fakultas Ekonomi Universitas Muria Kudus.

http://bandung.bpk.go.id/?p=4439. Diunduh tanggal 26 Oktober 2015.

http://nasional.kompas.com/read/2013/09/02/14143 57/Ini.Peringkat.Indonesia.Governance.Index.2 012. Diunduh tanggal 8 Agustus 2016

http://wartaekonomi.co.id/read/2015/02/16/45750/b pk-minta-pemda-perbaiki kualitas-laporankeuangan.html. Diunduh tanggal 26 Oktober 2015

http://www.antaranews.com/berita/468227/bpk-

sebut-kualitas-laporan-keuangan-daerah-masihrendah. Diunduh tanggal 26 Oktober 2015

http://www.pikiran-rakyat.com/node/171153.

Diunduh tanggal 26 oktober 2015.

www.bpk.go.id/ihps. Diunduh tanggal 18 Februari 2016. 